\title{
TOXIC EFFECT OF MALATHION IN TILAPIA NILOTICA
}

\author{
Abou-Rawash, A. A., Elsawak, A. A. and Nagwan M. Habashi \\ Pathology Dept., Fac. Vet. Med. Kafrelsheikh University
}

\begin{abstract}
Toxic effect of malathion in Tilapia nilotica fish after short (one month) and long (5 months) term exposure as well as reversibility of the lesions were investigated. The result showed malthion has adverse effect on all vital organs of T. nilotica fish at both levels of exposure. Necrobiotic changes in the parenchyma of liver, kidney and heart Lamellar hyperplasia with lamellar fusion in gills and neuronal injuries and edema were all detected. Most of the lesions observed have been almost completely disappeared by 4weeks of withdrawal of malathion but the brain still showed focal subependymal edema accompanied with neuronal injury and edema of the nerve tract.
\end{abstract}

\section{INTRODUCTION}

Malathion (o.o-dimethyle phosphoro dithioate of diethyl mercapto succinate) is one of the widely used organophosphorus insecticide for the control of pests on field crops and domestic animals as well as in insects control programs. The occasional misuse of malathion provides the opportunity for its entry into aquatic environment (by direct application, spray drift, aerial spraying, washing from the atmosphere, run-off from agricultural land, discharge of effluents from factories and in sewage) and many non targeted species are adversely affected. Malathion can reach aquatic systems by. 
It has been proved that malathion is detected in fish tissues, water and soil sediment from Manzala lake and River Nile at variable concentrations $^{(22)}$ which some times exceeded the permissible limit in water canals in Kafr Elsheikh ${ }^{(15,12)}$.

There is shortage in chronic toxicity and reversibility studies, the aim of this work is to study the toxic effect of malathion in Tilapia nilotica fish after short (one month) and long (5 months) term exposure to the insecticide as well as studying the reversibility of its toxicity.

\section{MATERIAL AND METHODS}

\subsection{Animals:}

130 monosex male $\mathrm{T}$. nilotica fingerlings of $7.5 \pm 2.5 \mathrm{~g}$ body weight and 3 weeks old from a local fish hatchery were used in present study. The fishes were acclimatized under laboratory conditions for one week in 112 liter glass aquaria $(40 \times 40 \times 70)$ each containing 80 liters of water before begin of treatment. 20 fishes were kept in each aquarium. The water temperature varied from 18 to $28 \mathrm{c}^{\mathrm{o}}$. The fishes were fed daily on a commercial fish diet.

\subsection{Chemical:}

A commercial formula of $57 \%$ malthion (Nasr lathion) was used. Stock solution of $570 \mathrm{ug} / \mathrm{ml}$ was prepared by dissolving $1 \mathrm{ml}$ of the formula in one liter of water. Test basin solutions of 47.4 and $11.85 \mathrm{ug} / \mathrm{L}$ were prepared daily corresponding to1/5 and 1/20 of the Lc50 in T. nilotica after $24 \mathrm{hr}{ }^{(12)}$.

\subsection{One month toxicity study:}

In this study 40 fishes were treated with $47.4 \mathrm{ug} / \mathrm{L}(1 / 5 \mathrm{Lc50})$ of malathion for one month with daily change of the whole test solution. Ten were sacrificed every week till the end of a month. 


\subsection{Reversbility study:}

In this study 20 fishes were treated with $47.4 \mathrm{ug} / \mathrm{L}(1 / 5 \mathrm{Lc50})$ of malathion for one month with daily change of the whole test solution, then ten fishes were sacrificed 2 and 4weeks after withdrawal of treatment.

\subsection{Five months toxicity study:}

In this study 30 fishes were treated with $11.85 \mathrm{ug} / \mathrm{L}(1 / 20 \mathrm{Lc50})$ of malathion for five months with daily change of test solution. Ten fishes were sacrificed after 1,3 and 5 months of treatment

\subsection{Control fish:}

Included 40 fishes kept under the same experimental conditions but without treatment and 5 were sacrificed after 1,2,3,4,6,8 weeks, and after 3 and 5 months from begin of treatment.

\subsection{Examinations:}

All fishes were subjected to careful observation for clinical signs of toxicity.

\subsection{Postmortem examination and sampling:}

All dead and scheduled sacrificed fishes were submitted for careful postmortem examination and necropsy findings were recorded. Tissue specimens from brain, liver, kidney, spleen, stomach, intestine, heart andgills were collected.

\subsection{Histopathological examination:}

Suitable tissue specimens were collected and immediately fixed in $10 \%$ formalin solution for at least $24 \mathrm{hr}$, then processed, paraffin embedded, sectioned at $4-6 \mu$ thickness and routinely stained with haematoxylin and eosin, Oil red $\mathrm{O}$ and brussion blue stains, covered with DPX, dried and microscopically examined ${ }^{(3)}$. 


\section{RESULTS}

\subsection{Clinical manifestation}

Decrease in food consumption was a prominent constant observation from the first day of treatment. In acute toxicity study the fish showed respiratory manifestation represented by an increase in the opercular movement, gasping of air in addition to nervous manifestation in the form of circling for few seconds followed by depression and lay in the bottom and corners of the aquarium. In the five months study the fish showed depression, dullness and prominent Stunting in growth as a result of decrease in food intake or fastening in the last month of treatment. The mortality rate was 4 fish in one month toxicity study and 5 in five month toxicity study. All that clinical signs disappeared after cessation of treatment in reversibility study.

\subsection{Gross pathology:}

Macroscopical examinations revealed hyperaemia in most of the examined organs together with hemorrhage in liver, swelling in gall bladder and increased slime on gills. Pale areas were noticed in the liver after 3 and 4 week treatment in one month toxicity study and after 3 and 5 month treatment in five month toxicity study. No obvious gross lesions were detected in the reversibility study.

\subsection{Histopathology:}

\subsubsection{One month toxicity study (1/5 lc50):}

\subsection{1. a. Liver:-}

Vacuolar degeneration and rarefaction of the cytoplasm with occasional pyknosis of nuclei, congestion of sinusoids and perivascular haemorrhage and focal mononuclear cell infiltration which was sometimes accompanied with single cell necrosis were observed in liver 
after one and two weeks. Some hepatocytes were atrophied with deeply basophilic, shrunken and pyknotic nuclei. Proliferation of the bile ducts was observed in one case. The hepatic changes became more prominent and more frequent in almost all fishes after 3 and 4 weeks. Focal areas of necrosis with mononuclear cells infiltration in one case of pancreatic acinar cells necrosis were also recorded (Fig. 1A, B).

\subsection{1.b. Kidney:-}

Examination of the kidney revealed necrobiotic changes in proximal renal tubules in the form of vacuolar degeneration, coagulative necrosis where the cells became atrophied with homogenous, acidophilic cytoplasm and pyknosis of the nuclei. Intertubular haemorrhage, focal interstitial edema and mononuclear cell infiltration, increased cellularity of the glomeruli and mild fibroplasia with thickening of the bowman's capsule were also detected. The renal changes increased in severity and frequency with the increase in duration of exposure (Fig. 1C, D).

\subsection{1.c. Heart:-}

Myocardial haemorrhage and edema were observed after one week of treatment. After 2 and 3 weeks, features of early myocardiosis, (vacuolation and occasional hyalinization), interstitial edema, atrophy, haemorrhage and focal myolysis with mild cellular infiltration were present in myocardiaum. Vegetative endocardial hyperplasia was observed in few cases. After 4 weeks, similar changes were observed in most of the cases together with focal necrosis, myolysis and focal myogenic cell proliferation (Fig. 2).

\subsection{1.d. Brain:-}

Examination of the brain after one week revealed slight subependymal edema and hyperemia of the meninges. and optic tectum. 
After two weeks, slight focal edema of cerebral cortex which was mostly pericellular and occasionally accompanied with mild neuronal injury was also observed. After 3 weeks, The subependymal edema extended to include the stratum griseum periventriculare and /or stratum fibrosum periventriculare of the optic tectum in which, the edema was accompanied with leucoencephalomalacia. Pericellular edema was occasionally present and hyperaemia of the meninges was a common finding. ischemic and Chronic neuronal injury was observed in few cases. ischemic neuronal injury revealed complete chromatolysis and pyknotic nucleus, while Chronic neuronal injury was characterized by clumpy Nissl granules with irregular pyknotic nucleus and more or less basophilic cytoplasm. After 4 weeks of treatment, menengeal hyperaemia and focal slight subependymal edema were constantly observed. Hyperaemia was also present in optic tectum of some fish. Pericellular edema in the cerebral cortex. and edema of molecular and purkenji cell layers of the cerebellum and nerve tract with ischaemic neuronal injury was also noticed. leucoencephalomalacia was also present in some fish (Fig. 3).

\subsection{1.e. Gills:-}

Histopathological examination of the gills after one week of treatment revealed mild hyperplasia of the cells of the interlamellar junction accompanied with telangiectasis, edema and congestion in the gill arch and fusion of tips. After two weeks, Sloughing of the epithelium of the secondary lamellae and lamellar cells hyperplasia with lamellar fusion were recorded. Lamellar hypertrophy and elongation of the secondary lamellae were observed in some samples. Lymphocytic cell infiltration, edema and congestion in the gill arch were also noticed. 
After three weeks, hyperplasia of the mucous cells of the tips of the primary lamellae was a prominent finding. In addition to cellular infilteration, edema, congestion in the gill arch and lamellar cells hyperplasia and fusion with hypertrophy, elongation of the secondary lamellae were observed in most of the cases.

After four weeks of treatment, all previously mentioned lesions became more frequent and pronounced together with mononuclear cell and granular eosinophilic cell infiltration in gill arch and edema of the cartilage (Fig.4).

\subsection{1.f. Stomach:-}

Examination of the stomach revealed congestion, edema, and heavy mononuclear cell infiltration in the stratum compactum and lamina propria together with necrotic change of the gastric glands with focal necrosis of the covering epithelium and formation of microcysts in covering epithelium. Mild fibroblastic cell proliferation in stratum compactum and deep lamina propria with necrosis and atrophy of the covering epithelium of upper part of gastric glands were also frequently observed.

\subsection{1.g. Intestine:-}

The intestine revealed increase in goblet cells, necrotic change in the epithelial lining, mononuclear cell infiltration in lamina propria and lymphoid hyperplasia from the $1^{\text {st }}$ week of treatment. After 3 weeks, the increase in goblet cells became less frequent and necrosis and degeneration of the epithelial was found in groups of cells. While after 4 weeks, atrophy and shortening of the intestinal villi with denuding of the covering epithelium were observed. 


\subsection{1.h. Spleen:-}

After one week of treatment, the spleen revealed depletion of the lymphoid element and reduction in number and size with scant pigment of melanomacrophages centers (M.M.C) and sometimes with pyknotic nuclei. Individual melanomacrophages (M.M.) with granular golden brown pigment were noticed in few cases. After 2 weeks, lymphocytic depletion, necrosis and clumping of lymphoid cells with active histiocytosis were frequently observed. exhausted M.M.C together with few individual M.M. were present in majority of the fish. After 3 weeks, lymphocytic depletion was marked together with active histiocytosis. M.M.C showed degenerative change where the cells became vacuolated with pyknotic nuclei and both reduced cellular density and pigmentation.After 4weeks, lymphocytic depletion, active histiocytosis and atrophy of M.M.C became marked. 2.3.3. Five month toxicity study $(1 / 20$ lc50) :

\subsection{3.a. liver:-}

The liver after one month of treatment revealed mild to moderate ill-defined vacuolation of the hepatocytes and pancreatic acinar cells. Circumscribed vacuolation of signet ring appearance was sometimes observed with hepatic cell atrophy. focal perivascula mononuclear cells with eosinophilic granular cells were also occasionally noticed. After three and five months, the liver revealed more frequent similar changes. Some of the sinusoids were dilated and others showed activation of sinusoidal cells. In few cases interlobular fibroplasia was evident with extensions between groups of severely vacuolated hepatic cells producing capsule like structures which may indicate beginning of pericellular fibrosis (fig. 64). Perivascular mononuclear and eosinophilic granular cell inflterations were also noticed with occasional hepatic cell Kafrelsheikh Vet. Med. J. Vol. 5 No. 2 (2007) 
necrosis. Intracellular apoptotic bodies (small rounded eosinophilic intracytoplasmic bodies) were observed within hepatic. In majority of cases the hepatopancreas revealed vacuolation of acinar cells and sometimes necrosis. (Fig. 5).

\subsection{3.b. Kidney:-}

Necrobiotic changes in the convoluted tubules, varied from hydropic dgeneration and pyknosis of nuclei to coagulative necrosis as well as Congestion were detected after one month of treatment in most of the cases. After three and five months, the same lesions observed after one month were present in addition to, cell vacuolation of the collecting tubules and atrophy of some convoluted tubules (Fig. 6A, B).

\subsection{3.c. Heart:-}

Myocardial haemorrhage and edema in most of the fish with Focal myocardial necrosis and moderate to sever myocardial atrophy were observed after one month. Fat vacuoles of different size (myocardial adiposis) and focal necrosis with pronounced myocardium atrophy in both atrium and ventricle together with edema and haemorrhage were all observed after 3 months of treatment. While after 5 months, atrophy, vacuolation, focal necrosis of the myocardium in addition to myogenic cell proliferation were observed in most of the fish (Fig. 6C, D).

\subsection{3.d. Brain:-}

The brain after one month of treatment revealed slight to moderate subependymal edema with occasional neuronal swelling and tigrolysis accompanied with satellitosis and focal microgliosis. Similar changes were found after 3 months of treatment. After 5 months, focal subependymal edema and edema in the cerebral cortex was observed more frequently. ischaemic neuronal injury characterized by complete $\overline{\bar{K} \text { Kafrelsheikh Vet. Med. J. Vol. } 5 \text { No. } 2 \text { (2007) }}$ 
chromatolysis, eosinophilic cytoplasm and pyknotic nuclei was present within the areas of cerebral edema. a single large vacuole in the soma of the neuron was occasionally observed. Edema of nerve tracts with pressure atrophy of the surrounding tissue was also observed (Fig.7).

\subsection{3.f. Stomach:-}

The histopathological examination of the stomach after one month of treatment revealed atrophy and focal necrosis of the covering and glandular epithelium together with dilatation of the gastric glands in some cases. Mild edema and mononuclear cell infiltrations were also observed in lamina propria and stratum compactum of some fish. After 3 and five months, as after one month, necrosis and /or atrophy of the covering and glandular epithelium and dilatation of the gastric glands were observed more frequently together with edema and mononuclear cell infiltration of the stratum compactum. Frequently, the glandular atrophy was accompanied with cystic dilatation of gastric glands and vacoulation of covering and glandular epithelium(Fig.8A, B).

\subsection{3.g. Intestine:-}

Atrophy of the covering epithelium with denuding and shortening of the villi and slight increase in fibroblast in lamina propria were observed after one month of treatment. Mononuclear cell infiltrations and lymphoid hyperplasia were also frequently observed in lamina propria .

similar changes were also observed after 3 and 5 months, with increase of goblet cells, hyperplasia of the covering epithelium, shortening and thickening of the villi (Fig.8 C, D).

\subsection{3.e. Gills:-}

The gills after one month of treatment revealed lameller hyperplasia and hypertrophy specially at the tips of the primary lamellae. Edema of the cartilage of the primary lamellae, lamellar fusion with destruction of $\overline{\text { Kafrelsheikh Vet. Med. J. Vol. } 5 \text { No. } 2 \text { (2007) }}$ 
secondary lamellae was also observed. in addition to edema and congestion, mononuclear cell and granular eosinophilic cells infiltration were observed in the gill arches after 3 months.

Marked lamellar hyperplasia, hypertrophy and fusion in addition to mucous cell hyperplasia at the tips of the primary lamellae with congestion and edema of the cartilage were observed after 5 months (Fig.9A, B).

\subsection{3.h. Spleen:-}

Moderate to sever lymphocytic depletion with active histiocytosis, increased hyaline bodies in the sinusoids were observed in the spleen one month after treatment. The M.M.C varied from normal heavily pigmented to ill-defined or individual M.M.C. After 3 months, sever lymphocytic depletion with active histiocytosis was observed in most of the fish. The M.M.C in other cases showed obvious exhaustion in which the center transformed to reticular net with presence of few atrophied melanomacrophages and few lymphoid elements.

After 5 months, marked lymphocytic depletion with active histiocytosis and marked exhaustion of Melaomacrophage centers which became smaller and represented by few degenerated cells. Evidence of splenic atrophy indicated by more prominent approximated trabeculae was also observed.

\subsubsection{Reversibility study:}

Although some lesions were still observed after 2 and 3 weeks of withdrawal of malathion, Most of the hepatic, renal, splenic, gastric and cardiac as well as gills lesions observed in have been almost completely disappeared by 4 weeks of withdrawal of malathion. But the brain still showing focal subependymal edema accompanied with neuronal injury and edema of the nerve tract in few cases( Fig. 9C, D). 


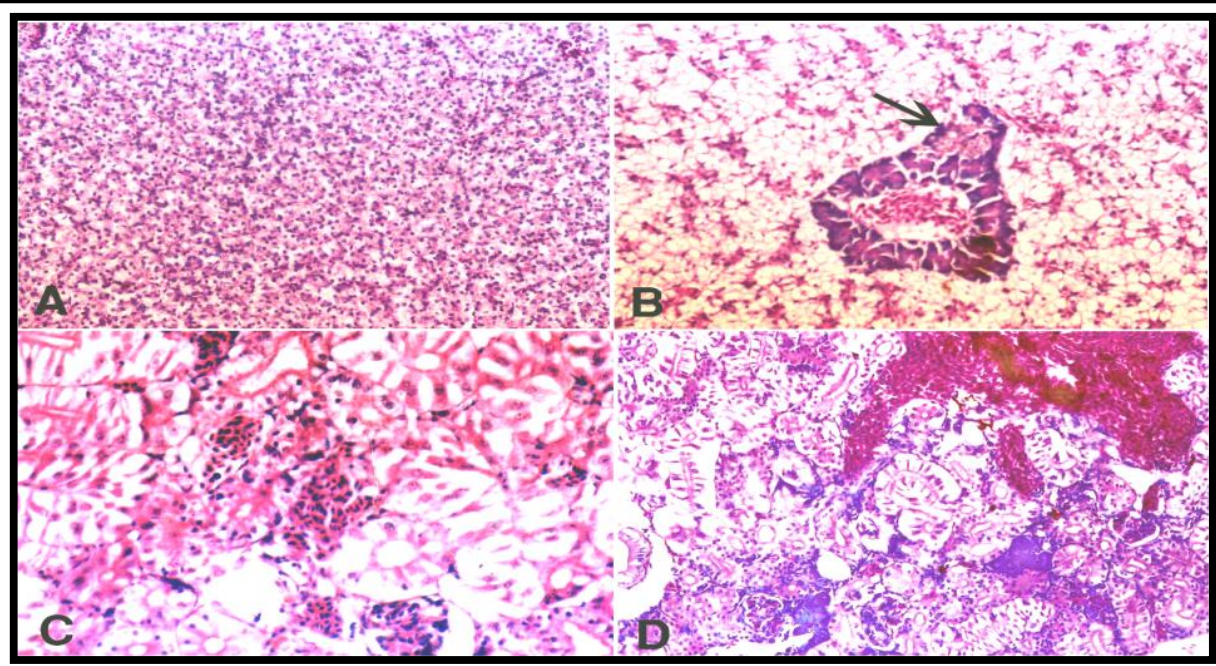

Fig.(1): liver showing atrophy of hepatocytes (A), Vacoulation of hepatocytes and necrosis of pancreatic acinar cells (arrow) B.Fig1 C Kidney showing vacuolation and necrosis of tubular epithelium (C), Necrosis of tubular epithelium and focal mononuclear cells infiltration (D).

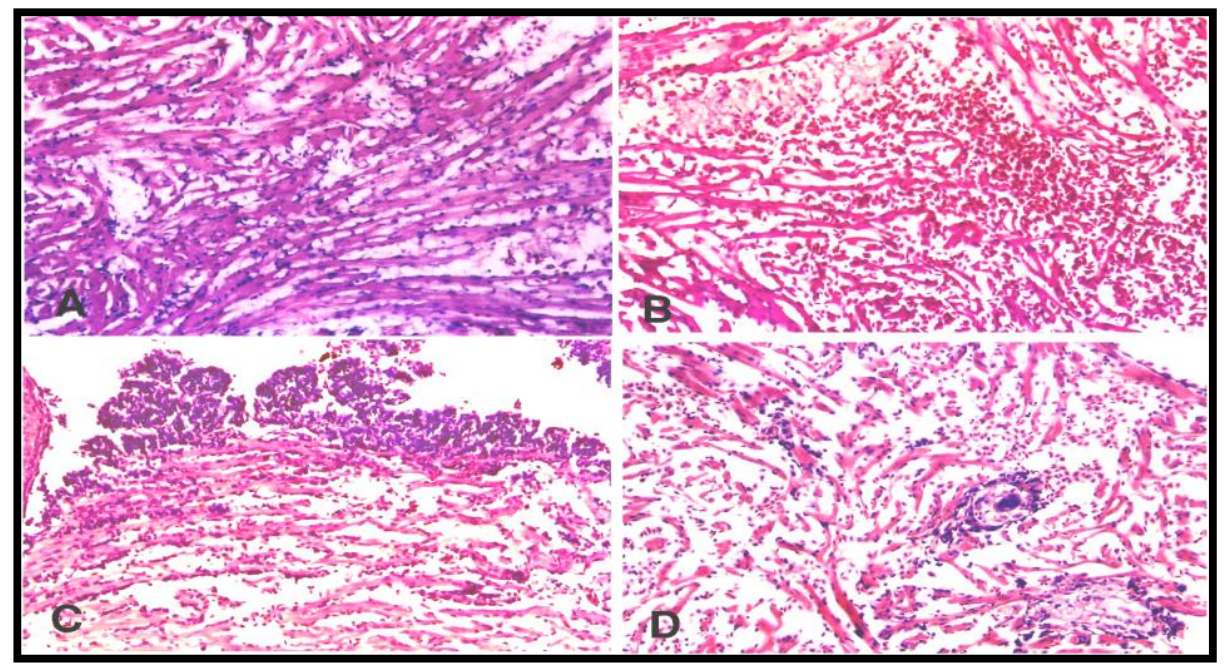

Fig.(2): Heart after 2 weeks showing, features of early myocardiosis, notice hyalinization of some myocardial fibers (A), haemorrhage, edema together with myocardial atrophy and focal myolysis (B), vegetative endocardial hyperplasia with myocardial edema and cellular infiltration (C), edema, haemorrhage and atrophy with focal necrosis, myolysis and myogenic cell proliferation after 4 weeks. (H\&E X 200). 
Toxic Effect Of Malathion In Tilapia Nilotica ...

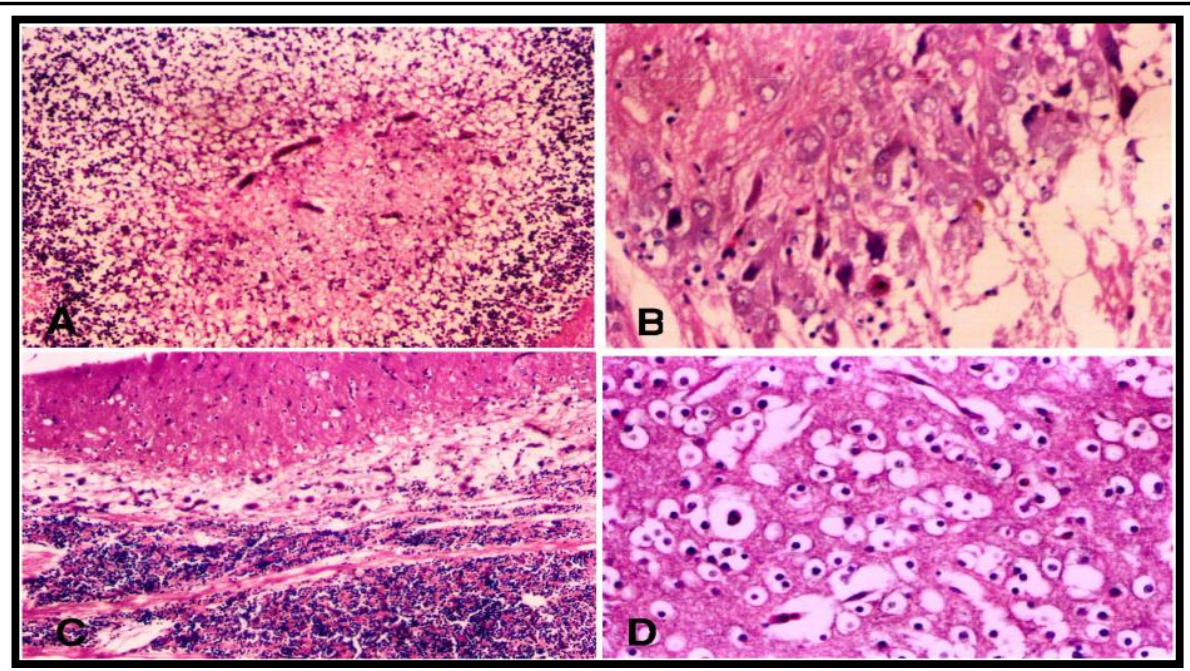

Fig.(3): Brain after 3 weeks showing (A) leukoencephalomalacia in optic tectum, edema and vacuolization of strum fibrosum perivenrticulare in cerebrum., (B) chronic ischemic neuronal injury. After 4 weeks showing (C) edema of molecular and purekinji cell layers of cerebellum., (D) pericellualr edema in cerebral cortex., (H\&E X 200).

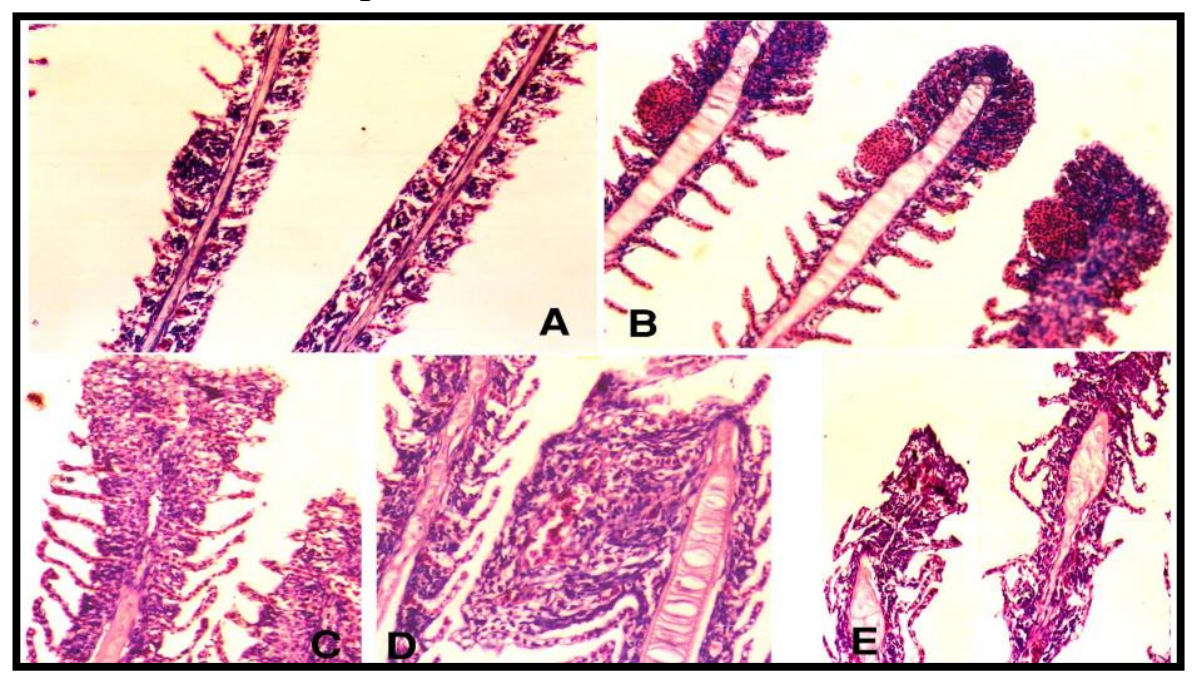

Fig.(4): Gills after one week showing mild interlamellar hyperplasia (A), with fusion at the tips of the primary lamellae (B), and lamellar fusion, hypertrophy and elongation of the secondary lamellae after 2 weeks (C) \& (D), in addition to edema of the cartilage of the primary lamellae after 4 weeks (E). (H\&E, x 200). 


\section{Abou-Rawash \& et al.,}

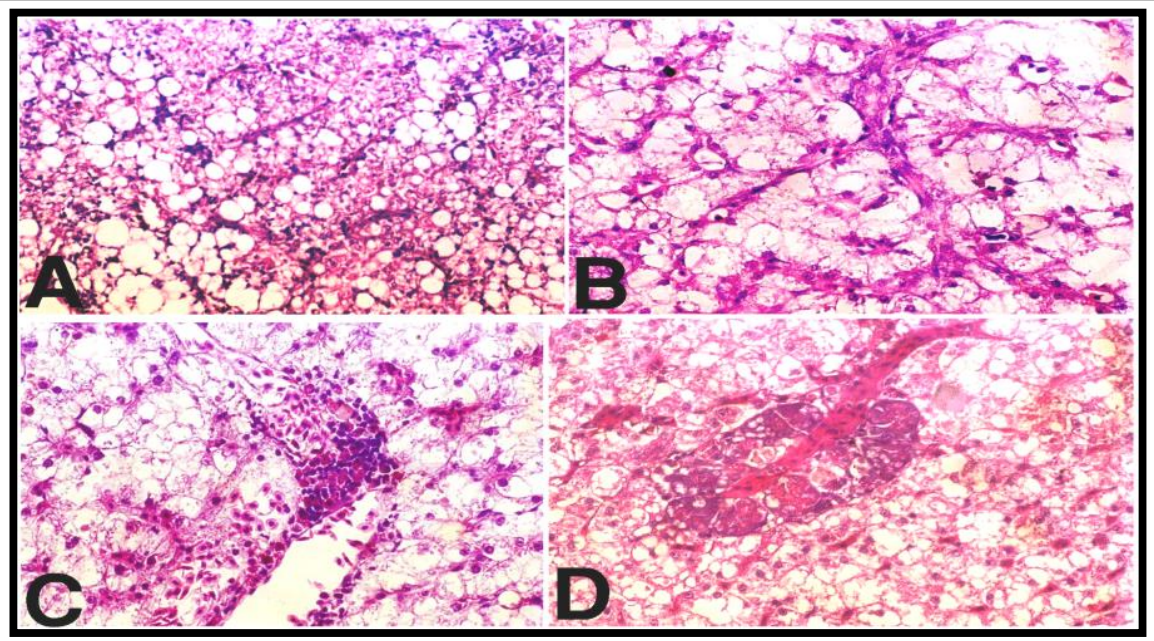

Fig.(5): liver showing, well defined vacuolation in the hepatocytes with hepatocytic atrophy and nuclear pyknosis (A), ill defined vacuoles and pyknosis of the nuclei (B), focal perivascular mononuclear and eosinophilic granular cell infiltration (C), well defined vacuolation of hepatocytes and vacuolation and necrosis of the pancreatic acinar cells (D), ( (H\&E, X 200).

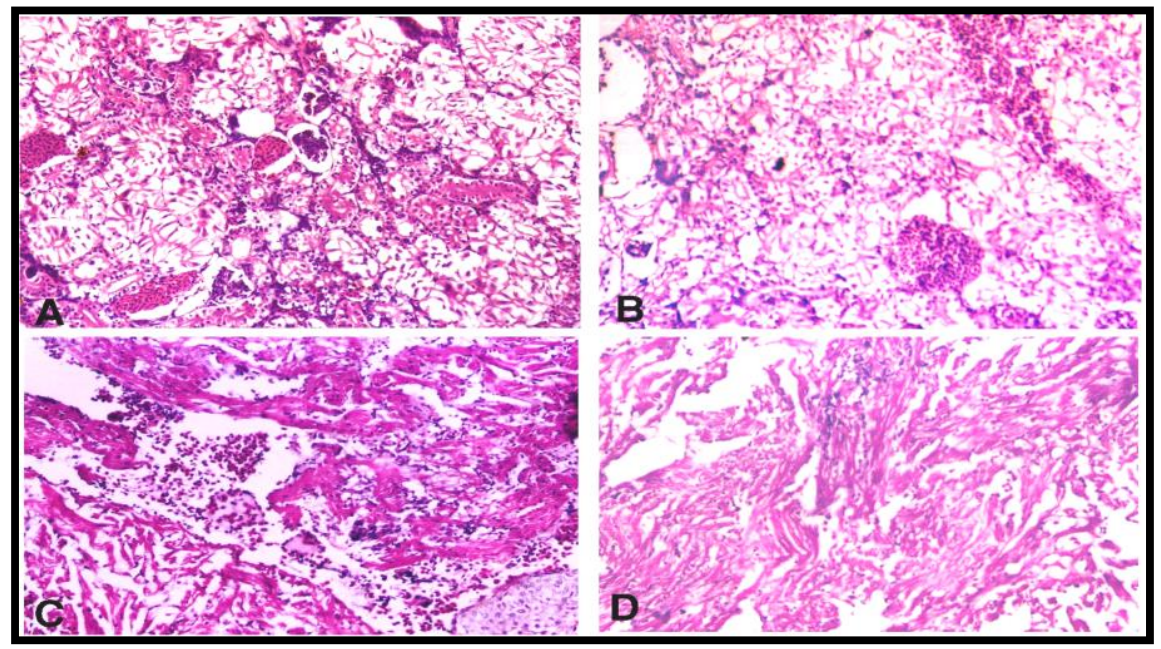

Fig.(6): Kidney showing, coagulative necrosis of the proximal convoluted tubules (A), necrosis and vacuolation of the collecting ubules (B). Heart Showing myocardial necrosis, myogenic cell proliferation, edema and haemorrhage $(\mathrm{C})$, in addition to vacuolation and atrophy of the myocardium (D). (H\&E, 10x 20). 


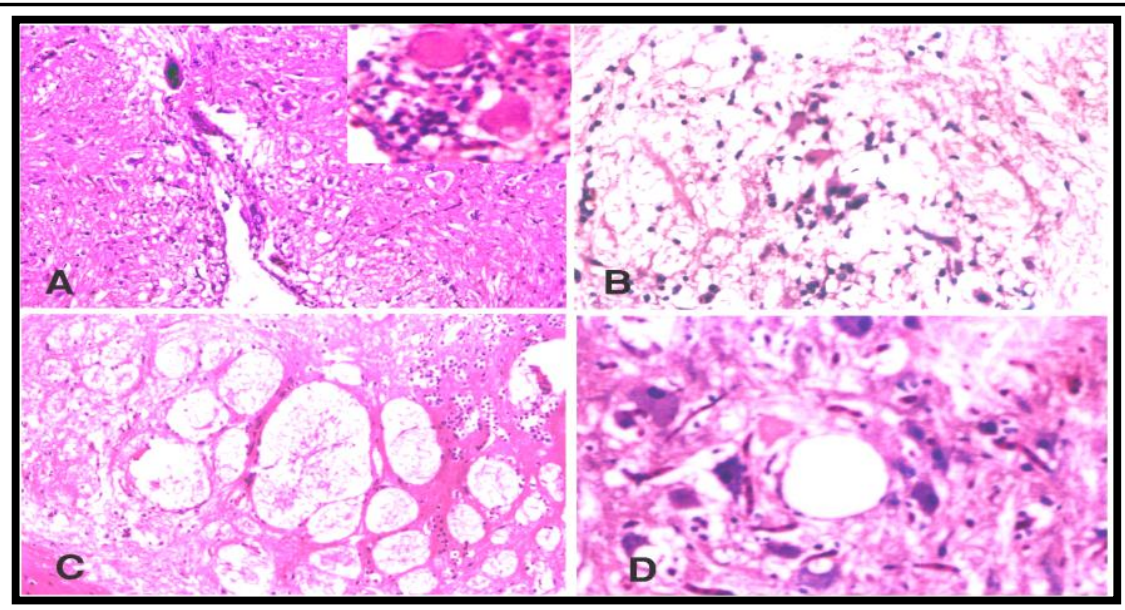

Fig.(7): Cerebrum (A) after 1 month showing subepindimal edema with tigrolysis and satillatosis (incient)., after 5 month showing (B) edema and ischemic neuronal injury., (C) edema in nerve tracts with pressure atrophy of neuropile., (D) neuronal injury, notice pyknosis and vacuolization, (H\&E X 200).

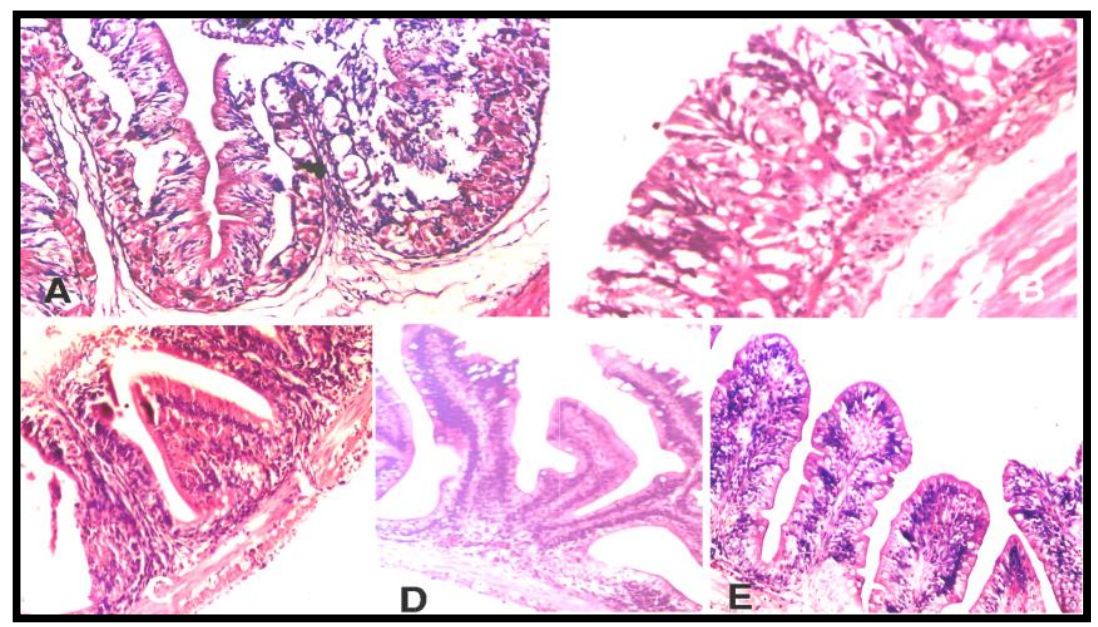

Fig.(8): Stomach (five month toxicity study ) showing, atrophic necrosis of the covering and glandular epithelium with cystic dilatation of the glandular crypts (A), (B). Fig. ( c) intestine showing atrophy and denuding covering epithelium with shortening of the villi and increase in fibroblast in the lamina propria (C) showing, mucosal hyperplasia with secondary villi formation(D) hyperplasia of goblet cells with villus shortening and fibrosis, (E). (H\&E, X 200). 


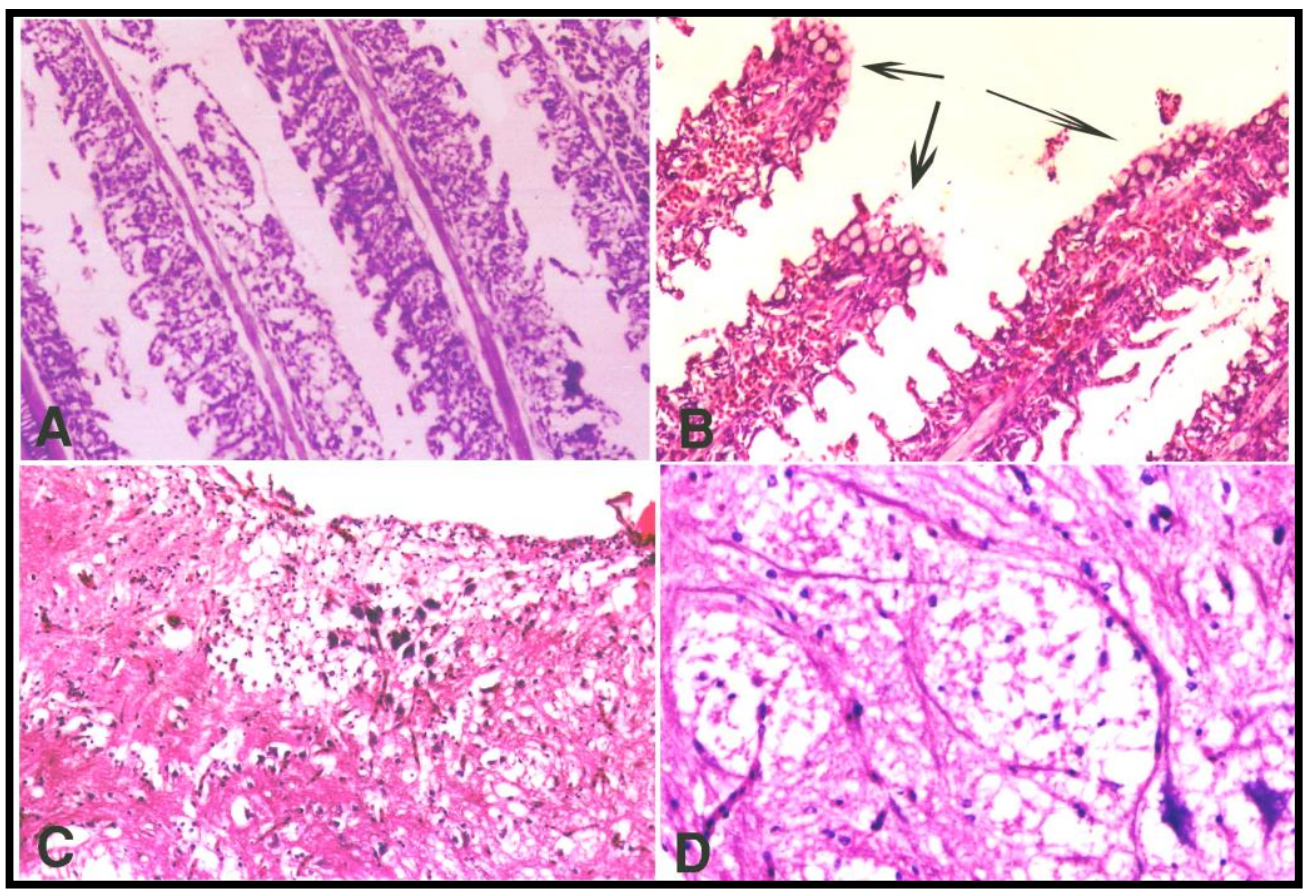

Fig.(9): Gills after 5 months exposure showing diffuse lamellar hyperplasia and fusion (A), in addition to hyperplasia of mucous cells (arrow) (B). Brain 4 weeks after withdrwal of malthion still showing subependymal edema with chronic neuronal injury (pyknosis and dark staining) (C); and edema of nerve tract (D).

\section{DISCUSSION}

Histopathological examination after exposure to malathion revealed lesions in different organs of the fish. The liver was one of the highly affected organs, this is regarded as the result of the presence of high residue levels in the liver in comparison to other organs ${ }^{(10,16)}$. In addition the liver is the main organ where bioactivation of malathion takes place $^{(28)}$. More or less similar pathological findings were reported in female catfish after exposure to malathion $(1.2 \mathrm{mg} / \mathrm{L})^{(6)}$. The prominent 
atrophy of hepatic cells in present study particularly in five month toxicity could be related at least partly to long period interference with protein synthesis. However, our results are in agreement with others $^{(1,2,15)}$. The presence of ill defined vacuolation and disappearance of the well defined vacuoles in the one month toxicity study could be attributed to the direct effect of malathion on the metabolism of the hepatocytes as it has been reported ${ }^{(26)}$. In addition association of hyperglycemia with mobilization of liver glycogen as a result of exposure to variable sublethal concentrations of organophosphate compounds was reported ${ }^{(2)}$.

In the five month toxicity experiment, the variability of the vacuolation between hydropic degeneration and glycogen and/or fat storage may be related to low dose and long duration of the experiment where the fish may be adapted for the toxic effect of malathion. The dynamics of the stress response in mammals and to a certain extent in fish may result in either adaptation or exhaustion. Generally persistence of stress is characterized by an alarm phase during which the level of adrenaline rises rapidly causing mobilization of liver glycogen into blood glucose, this is followed by a resistance phase in which glucose level remains elevated and liver glycogen may or may not be reduced ${ }^{(18)}$. Moreover oxidatation of malathion to the active metabolite malaoxon occurred in the liver by monooxygenases leading to degeneration and necrosis of the cells and increased apoptosis in five month study ${ }^{(28)}$.

Histopathological examination of spleen revealed lymphocytic depletion and exhausion of MMC from the $1^{\text {st }}$ week of treatment while after 3 and 4 weeks, many of MMC showed degeneration and decrease in pigmentation and cellular density. The changes which completely Kafrelsheikh Vet. Med. J. Vol. 5 No. 2 (2007) 
resolved in reversibility study. Similar lymphoid depletion, were described in carpe fish ${ }^{(2)}$. Moreover, El Bagory ${ }^{(11)}$ mentioned that malathon induced either activation or depletion of the hemopoietic elements together with lymphoid depletion in fresh water fish. Therefore, the lymphoid depletion and the changes in the melanomacrophage centers which reported in the present study could be attributed to the immune suppressive effect of malathion. Similar conclusion had also been reached by others. Indications of immune suppressive effect of malathion compound either by suppression of the generation of immunoglobulin or on the level of the cells by decreasing the total lymphocytic, eosinophilic, monocytic and neutrophilic cell count have been reported in some fish species. Suppression of antibodies agglutination in channel catfish after 30 days exposure has been reported (23), and administration of low doses of malathion for prolonged periods showed decrease in the levels of humoral immune response ${ }^{(21)}$, while single high dose was enough to suppress the generation of primary $\operatorname{IgM}$ in response to sheep R.B.Cs ${ }^{(19)}$. General decrease in differential lymphocytic, monocytic and neutrophilic counts in O-niloticus exposed to malathionin was also reported ${ }^{(1)}$.

Histopathological examination of the heart revealed myocardial haemorrhage and edema from the $1^{\text {st }}$ week of treatment. The heart also showed vacuolation, atrophy and necrosis of the myocardial muscle which varied from mild to sever. In reversibility study most of the lesions were completely disappeared after 4 weeks of withdraw of treatment. These findings are partly in agreement with the results reported in carp fish ${ }^{(2)}$. However, myocardial necrosis has been recorded in most of malathion treated rats for 15 days $^{(25)}$. 
The cardiac changes in the present study could be directly attributed to the toxic effect of malathion on the heart, or indirectly through decreased oxygen consumption which has been previously $\operatorname{recorded}^{(4,20)}$. Decreased oxygen consumption my induce anaerobic metabolism in the cells (glycolysis) with formation of lactic acid, a speculation supported by ${ }^{(26)}$ who stated that malathion depress The cellular oxidation and lead to development of anaerobic conditions.

The kidney showed vacuolar degeneration and occasional necrosis in the renal tubular cells of proximal convoluted tubules, increased cellularity of the glomeruli, hyperaemia and intertubular haemorrhage from the $1^{\text {st }}$ week of treatment, with focal peritubular mononuclear cell infiltration and begining of fibrosis in the glomeruli After 4 weeks. After 1 month the proximal convoluted tubules showed hydropic degeneration and coagulative necrosis with intertubular congestion. In addition vacuolation of the collecting tubules and atrophy of convoluted tubules were also observed after 3 and 5 months of exposure to malathion. These findings are in harmony with the previous reports of malathion toxicity ${ }^{(12)}$. The observed renal changes could be regarded as direct effect of malathion on renal component and structure through its elimination in the urine ${ }^{(5)}$. mentioned that the major part of malathion is excreted in the urine and faces within $24 \mathrm{hr}$ following oral administration in mammals.

The stomach showed congestion, edema and mononuclear cell infiltration in the stratum compactum and necrosis and atrophy of the covering epithelium and /or the gastric glands). Increase in goblet cells, necrosis and degeneration of the epithelium with shortening and atrophy of the intestinal villi with mononuclear cell infiltration in lamina propria 
and lymphoid hyperplasia were detected in intestine. similar GIT findings were recorded ${ }^{(1,20)}$. El-Dib ${ }^{(10)}$ reported high residues levels of malathion metabolites in the intestine and gills. suggesting that the two organs contain active xenobiotic enzymatic systems which act as defensive mechanism against toxic chemicals. The lesions reported in the GIT could be attributed to direct or indirect effect (metabolites and residues) of malathion.

The present results are more or less in agreement with brain finding reported after malathion in fish ${ }^{(2,11,12,25)}$.

The brain lesions could be attributed to the direct effect of malathion as a neurotoxin through its ability to block neurotransmission by inhibiting the enzyme, acetyl cholinesterase ${ }^{(8,29)}$, or indirectly through drop in brain glycogen upon which the brain tissue is dependent for its metabolism, ${ }^{(13,17,18)}$.

The gills are involved in different physiological processes of gas transfer and acid base regulation $^{(24)}$ as well as osmotic and ionic regulation ${ }^{(9)}$, they are considered the most vulnerable organs when there are changes in the ambient environment ${ }^{(7)}$.

Examination of the gills revealed lamellar hyperplasia, edema, congestion and cellular infiltration in addition to lamellar fusion and hypertrophy with elongation of the secondary lamellae and hyperplasia of mucous cells that persist for 2 weeks withdraw of malathion. Similar results were previously reported ${ }^{(1,11,14)}$.

The gills changes were regarded partly to its role in elimination of malathion as the mitochondria rich cells of the gills may function as excretory cells because they can provide MFO enzymes, molecular oxygen, reduced NADPH2, NADH2 ${ }^{(27)}$. 


\section{REFERENCES}

- Abbass, A.A., Ismail, R.S. and RAdwan, H.A. (2001): Clinicopathol-ogical findings, chromosomal aberrations and hematological changes associated with acute intoxication by malathion in Nile catfish (Clarias Lazera).Zag.Vet.J.,29:146157.

- Abd El-Rahman A.H. (1996): Effect of pollution with some pesticides on the hematological and biochemical profiles in fresh water fishes . A thesis, Fac .Vet . Med, Beni Suef, Cairo University .

- Bancroft , J.D. , and Stevens , A. (1996): Theory and practice of Histological techniques . Fourth Edition.

- Bashamohideen, M.,Obilesu,K.,Malla-Reddy,P.and Reedy, P.M .(1988): Effects of malathion and methyl parathion on the metabolic changes in fish Tilapia mossambica. Environment and Ecology., 6 (2): 481-483.

- Clive tomlin (1994): Insecticide Acaricide. In the pesticide Manual incorporating the agrochemicals hand book. Crop protection publications, Bcpc British Crop protection council, PP . 630-631.

- Dutta, H.M., Adhikari, S., Singh, N.K., Roy, P.K.,and Munshi, J.S.D. (1993): Histopathological changes induced by malathion in. The liver of afresh water catfish, Heteropneustes fossilis (Bloch). Bull. Environ. contam. Toxicol., 51:895-900.

- Dutta, H.M., Munshi, J.S.D., Roy, P.K., Singh, N.K., $\overline{\bar{K} \text { Kafrelsheikh Vet. Med. J. Vol. } 5 \text { No. } 2 \text { (2007) }}$ 
Adhikari, S. and Killius. J. (1996): Ultrastructural changes in the respiratory lamellae of the catfish, Heteropneustes fossilis after sub lethal exposure to malathion. Environmental Pollution.,92(3):329-341.

- Dutta, H.M., Munshi, J.S.D., Dutta, G.R., Singh, N.k., Adhikari, S., and Richmonds, C.R.(1995):Age relation differences in the inhibition of brain acetyl cholinesterase activity of Heteropneustes fossilis (Bloch) by malathion. Comparative Biochemistry and Physiology, A, Physiology., 111(2): 331-334.

- Eddy,F.B.(1982):Osmotic and ionic regulation in captive fish with particular reference to salmonids. Comp. Bio. Chem. Physiol., 7213:125-41.

- El -Dib, M.A., El-Elaimy, I.A. , Kotb, A. and Elowa, S.H. (1996): Activation of in vivo metabolism of malathion in male tilapia nilotica. Bull. Environ. Contam. Toxicol. , 57:667-674.

- El-Bagori,H.M.Z.(2000):Pathological studies on some environmental pollutants on some fresh water fish in sharkia governorate .A thesis, Department of Veterinary Pathology. Fac. Vet. Med. Zagazig University.

- El-Shaieb, A.F., Zaki, V.H. and El- AShram, M. (2001): Pathological studies on the side effects of some evironmental pollutants in Tilapia zilli.The second international scientific conference,the rolof veterinary medicine for community,Mansoura Unversity.,2:303-327.

- Gill,T.S., Pande, J. and Tewari,H.(1990): Physiological

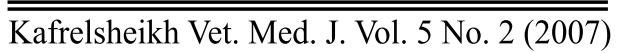


Energetics.In water pollution and fish physiology( $2^{\text {nd }}$ edition). Lewispublishers, BocaRaton, Newyork, London, Tokyo.pp.206.cited byHeath (1995).

- Goldes (1988): The pathophysiology and systematic pathology of teleosts; In Roberts, Ronald.J., Fish pathology, W.B. Saunders. London. Newyork. Sydney. Toronto.

- Hamed S.A.E. (1997): toxicological studies on some side effects on some environmental pollutants. A thesis, Fac .Agriculture, Kafr El-sheikh, Tanta University.

- Hassan, I.M., Abd Allah, M.A., Naguib, M.M., and AbouDonia, M.A. (1993): toxicity, distribution, accumulation and cooking loss of malathion in tissues of tilapia and common carp fishes.: Grasasy- Aceites., 44(6) 339-344.

- Hawkins,R.(1985): Physiological Energetics.In water pollution and fish physiology ( $2^{\text {nd }}$ edition). Lewis publishers, Boca Raton, Newyork, London, Tokyo. pp.206.

- Heath,Alan G.(1995): Physiological Energetics. In water pollution and fish physiology ( $2 \mathrm{~d}$ edition). Lewis publishers,Boca Raton, Newyork, London, Tokyo.pp.202-206.

- Khalaf-Allah, S.S. (1999): Effect of pesticide water pollution on some haematalogical, biochemical and immunological parameters in tilapia nilotica fish. Bibliographic citation : Deutsche tierarztliche - wochenschrift., 106(2): 67-71.

- Khillare,Y.K.andWagh,S.B.(1988): Long term effects of pesticides endosulfan, malathion and sevin on the fish puntius stigma. Env. and Ecology. 6(3):589-593. 
- Olefir,A.I.and Minster,O.P.(1977):Natural immunity of the organism as a function of the intensity of pesticide exposure. Varch-Delo., 9:121-127.

- Osfor, M.M.H., Abd-El-Wahab, A.M., El-Dessouki, S.A., (1998): Occurrence of pesticides in fish tissues, water and soil sediment from Manzala lake and River Nile. Nahrung., 42(1) $39-41$.

- Plumb and Areechon (1990): The immune system. In Health, Alan G. Water pollution and fish physiology CRC. Lewis publishers. Boca Raton New york.

- Randall,D.J.,Perry,S.F.andHeming,T.A.(1982): Gas transfer and acid base regulation in salmonids. Comp. Biochem. Physiol., $73 \mathrm{~B}$, 93-103.

- Rashed,Amany.Y.M.and Darwish, Fatma. M.M.(2002): Protective effect of casein and/or ascorbic acid on some metabolic and pathological changes induced by malathion insecticide in rats. Vet. Med. J., Giza., 50 (4): 447-473.

- Reddy, P. Sreenivasula., Bhagyalakshmi, A. and Ramamurthi, $\boldsymbol{R}$. (1986): Chronic malathion toxicity: Effect on carbohydrate metabolism of oziotelphusa senex senex, the Indian rice field crab. Bull. Environ. contam. toxicol., 37:816822.

- Srivastava , A.K. (1988): Acute toxicity of malathion and its antidotal treatment with diacetyl monoxieme and atropine in

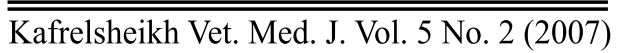


Bubalis. In environment and pesticide toxicity, ed. R.C. Dalela,

S. kant and S. Vohra. The academy of environmental Biology, India, PP. 235-41.

- Walker, C. H.(1994): Comparative toxicology. InHodgson, Ernest and Levi, Patricia. E. Introduction to biochemical toxicology. Appleton, lange, 25 van zant street, Norwalk, Connecticut. pp. 210-211.

- Waxman, M. F. (1998): Toxicology and mode of action In agrochemical and pesticide safety handbook. Lewis publishers, Boca Raton, Boston London New york. PP132-135.

$$
\text { در اسات باثولوجية عن التأثثر السمي للملاثيون في البلطي النيلي }
$$

تم استخدام 130مـن اسماك البلطي النيلى لدراسـة التأثنيرات الباثولوجيـه التي قد تنجم عن استخدام مادة الملاثيون بجرعات 20/5،1/1من الجرعة المميتة (237.0ميكرو جرام / لتر) لمده شهر واحد وخمسه انشهر على التوالي. وبالفحص التشريحي الدقيق والفحص المجهري لوحظ وجود إستحالات فجوية في السيتوبلازم مع صغر حجم الأنوية فى الخلايا الكبدية بالإضافة إلى وجود احتقان في الأوعية الامويـة وإرتثـاحات خلوية حول الأوعية الدمويـة خاصـة .كما لوحظ تكاثر فى عدد القنوات المراريـة وكذلك وجود انزفه بين خلايا الكبد . كما وجدت فجوات صغيره فى حويصلات البنكرياس .كما لوحظ أيضاً وجود ضمور وموت فى خلايا الكبد مع ظهور نخر فى خلايا فرديه. لوحظ كذلك وجود ارتثاح مائي و احتقان في الأوعية الدموية للأغشية السحائية و الفص البصري مـع وجود ارتثـاح مائي في القتـرة المخيـة حول الخلايـا المخيـة العصبية و كذلك تتكرز مخي وإصـابات مزمنـة للخلايـا العصبية المخية. كما لوحظ أيضا وجود ارتنتاح مائي في القنوات العصبية و المخيخ. ظهرت أنزفة بين ألياف 
عضلات القلب و ارتشاح مائي و وفجوات فى عضلات القلب مع زيادة فى عدد الخلايا المبطنه للقلب مع وجود موت وضمور فى عضلات القلب. أظهرت الكلى وجود فجوات وموت للخليا المبطنة للجزء القاصى (العلوى) من النفرون بالإضـافة الى زيادة عدد خلايا الكبيبات مع وجود ارتثـاح بينى للخلايا الالتهابية وحيده النواه ونزيف وارتتـاح مائى. وكنللك لوحظ احتقان في الأوعية الدموية و ارتثاح مائى وارتثاح لخلايا التهابية وحيده النواه في الأساس من الطبقة الطلائية والطبقة الضامة مع وجود ضمور وموت للخلايا الغدية للمعدة. لوحظ أيضاً زيادة في عدد الخلايا الكأسية و ضمور وموت في الخلايا

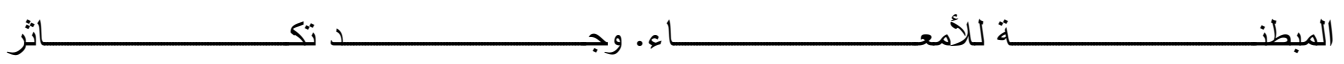
والتصاق للصفائح الخيشومية وارتثـاح مائي واحتقان في الأوعية الدموية وارتتـاح لخلايا وحيده النواة وعديدة النواة في القوس الخيشومي. 